\title{
Ovary cord micromorphology in the blood-sucking haemadipsid leech Haemadipsa japonica (Hirudinida: Arhynchobdellida: Hirudiniformes)
}

\section{$\operatorname{AUTHOR}(\mathrm{S}):$}

Urbisz, Z., Anna; Nakano, Takafumi; witek, Piotr

\section{CITATION:}

Urbisz, Z., Anna ...[et al]. Ovary cord micromorphology in the blood-sucking haemadipsid leech Haemadipsa japonica (Hirudinida: Arhynchobdellida: Hirudiniformes). Micron 2020, 138: 102929 .

\section{ISSUE DATE:}

2020-11

URL:

http://hdl.handle.net/2433/254676

\section{RIGHT:}

(c) 2020. This manuscript version is made available under the CC-BY-NC-ND 4.0 license

http://creativecommons.org/licenses/by-nc-nd/4.0/:; The full-text file will be made open to the public on 1 November 2021 in accordance with publisher's 'Terms and Conditions for Self-Archiving'.; This is not the published version. Please cite only the published version.; この論文は出版社版でありません。引用の際には出版社版をご確認ご利用ください。 
Ovary cord micromorphology in the blood-sucking haemadipsid leech Haemadipsa japonica (Hirudinida: Arhynchobdellida: Hirudiniformes)

Anna Z. Urbisz ${ }^{1 *}$, Takafumi Nakano ${ }^{2}$ and Piotr Świątek $^{1}$

${ }^{1}$ Institute of Biology, Biotechnology and Environmental Protection, University of Silesia in Katowice, 40-007, 9 Bankowa St., Poland

${ }^{2}$ Department of Zoology, Graduate School of Science, Kyoto University, Kyoto 606-8502, Japan

*corresponding author: anna.urbisz@us.edu.pl

Original manuscript

Keywords: Annelida; germ-line cyst; intercellular bridge; nurse cell; oocyte. 


\section{Abstract}

This is the first report that describes histological and ultrastructural details of ovary organization in haemadipsid leeches. In Haemadipsa japonica, the female reproductive system is organized similar to that of other haemadipsids. Each of the paired and oval ovaries of $H$. japonica is comprised of the ovary wall (ovisac), which encloses two elongated, threadlike ovarian units termed ovary cords. Ovary cords are comprised of germ-line cells and associated somatic cells. Each cord is polarized and contains germ-line cells in the consecutive developmental stages that are sequentially located along the long cord axis. There were three zones in each cord: the club-shaped apical part, the thread-like middle part, and the basal-most end, which contains degenerating germ cells. Outside of the reproductive period, the middle part of the cord in leeches is smooth, and no growing oocytes are visible; alternatively, in mature specimens, several growing oocytes protrude from the cord, and several huge vitellogenic oocytes that are completely detached from the cord occur within the ovisac. Ovary cord organization and functioning in $H$. japonica are very similar to the 'Hirudo' type cords that were found in several hirudiniform leeches. This conclusion supports the view that all hirudiniform leeches have conservative ovary cord organization and a similar pattern of oogenesis. Germ-line cyst composition, architecture, and functioning were also found to be evolutionarily conservative characteristics when compared with all previously examined Clitellata. In the germ-line cysts found in $H$. japonica each cell is connected to the central and anuclear cytoplasmic mass (cytophore) via one intercellular bridge, and, as oogenesis progresses, the fate of interconnected cell diversifies: some of them (oocytes) grow and complete oogenesis, but the majority become nurse cells and finally degenerate. Thus, oogenesis in H. japonica, similar to other clitellates, can be considered meroistic. 


\section{Introduction}

Haemadipsid leeches are well-known blood-feeding species that inhabit humid forests of the Indo-Pacific region, and they attack humans and vertebrate animals. Originally, the family Haemadipsidae included all terrestrial leeches, which possess five pairs of eyes that form a broad ocular arch ('haemadipsine' ocular arch) and have lateral nephridia (Blanchard, 1896, 1917). Contemporary analysis based on $18 \mathrm{~S}$ rDNA, 28S rDNA, and COI sequences and numerous morphological traits (Borda et al., 2008; Borda and Siddall, 2011) found that Haemadipsidae is a monophyletic family of blood-sucking terrestrial leeches only from the Indo-Pacific region; they proposed dividing this family into three subfamilies: Haemadipsinae for Haemadipsa species, Domanibdellinae for numerous monotypic genera, and Titetrabdellinae for Sinospelaeobdella canvatuses and the genus Tritetrabdella.

Haemadipsidae were also traditionally divided based on jaw morphology: Haemadipsinae and Titetrabdellinae have three jaws (trignathous haemadipsids), whereas Domanibdellinae have two jaws (duognathous haemadipsids) (Borda and Siddall, 2011). Approximately 70 species belong to Haemadipsidae, of which there are 24 in the most speciose genus, Haemadipsa (Borda and Siddall, 2011). Haemadipsid leeches, because of their unusual terrestrial habit and food preferences, have been quite intensively analyzed in the context of their distribution, biology, ecology, and taxonomy (reviewed in Borda et al., 2008; Borda and Siddall, 2011). Recently, these leeches became a popular source of invertebrate-derived ingested DNA for biodiversity inventorying (e.g. Schnell et al., 2015; Tessler et al., 2018; Hanya et al., 2019; Fahmy et al., 2019). However, there is a lack of information available on their internal body organization. Aside from general morphological descriptions of some organs and internal systems (especially reproductive systems - see below), more detailed analyses (histological, ultrastructural) of haemadipsid leeches are extremely rare. The sperm ultrastructure in Haemadipsa zeylanica was presented by Ben 
Ahmed et al. (2015), whereas Tessler et al. (2016) applied computed tomography to reveal internal diagnostic features in their description of a new species.

As in the case of other clitellate annelids (Clitellata), the organization (morphology and localization) of leech reproductive systems is an important diagnostic feature with many taxonomically informative characters (e.g. Sawyer, 1986; Borda and Siddall, 2008; Govedich and Moser, 2015). The general organization of the haemadipsid reproductive system is quite well known, and this information is usually provided with species descriptions (e.g. Lai et al., 2011; Huang et al., 2019). However, there are no data on the histology and ultrastructure of their reproductive organs. During the last two decades, the histological and ultrastructural details of leech ovary organization and the course of oogenesis have been described in several taxa, such as Alboglossiphonia heteroclita (Glossiphoniidae, Świątek 2005, 2006); four Piscicola species (Piscicolidae, Spałek-Wołczyńska et al., 2008); Erpobdella octoculata and E. johanssoni (Erpobdellidae, Świątek. et al., 2010; Ben Ahmed et al., 2013); Barbronia weberi (Salifidae, Urbisz et al., 2014); Hirudo medicinalis, H. troctina and Limnatis nilotica (Hirudinidae, Świątek 2008; Ben Ahmed et al. 2010); and Haemopis sanguisuga (Haemopidae, Świątek 2008). These data together with numerous older reports (reviewed in Świątek and Urbisz, 2019) allowed recognition of four different types of internal ovary organization in Hirudinida (Świątek and Urbisz, 2019; see Discussion). To date, little variation among internal ovary organization has been observed within any leech family; thus, if this character is consistent at least at the family level, it could be useful for phylogenetic analyses (Świątek and Urbisz, 2019). In fact, the morphological and ultrastructural features of leech reproductive systems were used to further elucidate leech phylogeny (Bielecki et al., 2014). Taking into account the lack of data about histological and ultrastructural organization of ovaries in haemadipsid leeches, we performed light and electron microscopic analysis of 
this organ in Haemadipsa japonica. Then we compared the results obtained with data concerning other true leeches, especially Hirudiniformes.

\section{Material and Methods}

\subsection{Specimen collection}

Haemadipsa leeches were collected from four localities in Japan during 2011-2018: Takidanitoge Pass, Kyoto, Honshu Island $\left(35^{\circ} 08^{\prime} \mathrm{N}, 135^{\circ} 45^{\prime} \mathrm{E}\right)$ on 1 November 2011 ; the University of Tokyo Chiba Forest, Chiba, Honshu Island $\left(35^{\circ} 08.4^{\prime} \mathrm{N}, 140^{\circ} 09.1^{\prime} \mathrm{E}\right)$ on $11 \mathrm{June}$ 2012; Nibetsu, Akita, Honshu Island (39 $\left.47^{\prime} 48.6^{\prime \prime} \mathrm{N}, 140^{\circ} 14^{\prime} 06.6^{\prime \prime} \mathrm{E}\right)$ on 3 September 2014; Hakiai, Kumamoto, Kyushu Island (32 $\left.24^{\prime} 50.1^{\prime \prime} \mathrm{N}, 130^{\circ} 51^{\prime} 51.5^{\prime \prime} \mathrm{E}\right)$ on 21 October 2017; and Ko-no-tani, Nara, Honshu Island $\left(34^{\circ} 15^{\prime} 34.8^{\prime \prime} \mathrm{N}, 136^{\circ} 05^{\prime} 50.5^{\prime \prime} \mathrm{E}\right)$ on 4 August 2018. In total 20 specimens were used for analysis.

\subsection{Light and electron microscopy}

Leeches were narcotized with mineral water $\left(\mathrm{CO}_{2}\right)$, initially fixed with $2.5 \%$ glutaraldehyde in a $0.1 \mathrm{M}$ phosphate buffer ( $\mathrm{pH} 7.4)$, and then dissected. The whole reproductive systems or only gonads were fixed in $2.5 \%$ glutaraldehyde in the same buffer at room temperature for several days. After washing in a phosphate buffer, the material was postfixed for $1 \mathrm{~h}$ in $1 \% \mathrm{OsO}_{4}$ in the same buffer, dehydrated in a graded series of ethanol that was consequently replaced with acetone, and then embedded in an Epoxy Embedding

Medium Kit (Sigma, St. Louis, MO, USA). Serial semi-thin sections (0.7- $\mu$ m thick) were cut on a LEICA Ultracut ultramicrotome and stained with $1 \%$ methylene blue in a $1 \%$ sodium biborate solution at room temperature for $30 \mathrm{~s}$. Sections were examined under an Olympus BX60 microscope equipped with an XC50 digital camera (Olympus) and cellSens Standard software (Olympus). Ultra-thin sections (60-nm thick) were cut on an RMC Power XT 
ultramicrotome. Ultra-thin sections were contrasted with uranyl acetate (30 min) and lead citrate (20 min). Contrasted sections were examined using a Hitachi H500 electron microscope at $75 \mathrm{kV}$. The whole reproductive system was analyzed using Olympus X71 and Leica M125 stereomicroscopes.

Additionally, dissected ovaries were fixed in $4 \%$ formaldehyde (freshly prepared from paraformaldehyde) in phosphate buffered saline $\left(\mathrm{NaCl}, 137 \mathrm{mM} ; \mathrm{KCl}, 2.7 \mathrm{mM} ; \mathrm{Na}_{2} \mathrm{HPO}_{4}, 8\right.$ $\mathrm{mM} ; \mathrm{KH}_{2} \mathrm{PO}_{4}, 1.5 \mathrm{mM}, \mathrm{pH} 7.4$ ) for 30-40 min at room temperature. After washing in phosphate buffered saline ovaries were put onto microscopic slides, manually torn with tweezers to visualize ovary cords and analyzed under an Olympus BX60 microscope equipped with a Nomarski differential interference contrast.

\section{Results}

\subsection{Gross morphology of ovaries and ovary cords}

The Haemadipsa japonica female reproductive system was comprised of sac-like paired ovaries, and paired and thin lateral oviducts that joined into an unpaired common oviduct, which in turn inserted into the elongated vaginal sac (Fig. 1A). An elongated vaginal duct ran from the vaginal sac towards the body wall and ended in the gonopore at segment XII. Each ovary was made up of the ovary wall (ovisac), which enclosed the space filled with coelomic fluid; within the fluid, two elongated cord-like structures (ovary cords) were present (Figs. 1B, F, 2A). The ovary cords were tightly convoluted with each other and usually broke up into smaller fragments during dissection from ovisacs (Fig. 1B, F). Additionally, when the leech was sexually mature freely floating oocytes occurred within the ovisac cavity (Fig. 2A). Each ovary cord was a solid, string-like structure comprised of somatic and germ cells (Figs. 1B, F, 2A-E). Ovary cords observed under a stereomicroscope and Nomarski interference 
contrast showed that three regions in each ovary cord could be distinguished: a slightly expanded apical end, a string-like and highly convoluted middle part, and a short basal (degenerating) end (Fig. 1B-F). These regions were especially visible in specimens with ongoing oogenesis (Fig. 1C, E-F); alternatively, in non-breeding individuals, the degeneration zone was morphologically difficult to distinguish (Fig. 1B). The ovary cords were smooth (Fig. 1D), except during breeding season, when growing oocytes protruding from the middle part of the cord were visible (Figs. 1E, F, 2A). Below, we separately describe histological and ultrastructural properties of germ-line (germ-line cysts, growing oocytes) and somatic (ovisac and somatic cells found in the ovary cords) components of ovaries.

\subsection{Germ-line cysts and growing oocytes}

The vast majority of germ-line cells found in $H$. japonica ovaries did not exist as individual cells; instead, they were interconnected into syncytial groups of cells, known as cysts, clusters, or clones. The only individual germ cells found were some oogonia located close to the apical cell (Fig. 1C) and growing (vitellogenic) oocytes, which had already detached from ovary cords and freely floated in the ovisac lumen (see below; Fig. 2A). The germ-line cysts observed in $H$. japonica had specific organization; that is, cysts were comprised of numerous cells connected to the central cytoplasmic mass, which was common for a whole cyst and devoid of cell nuclei - this cytoplasmic mass is known as a cytophore (Fig. 2C, D). Each germ cell was connected to the cytophore by a single canal-like intercellular junction termed an intercellular bridge or ring canal (Figs. 2C, 3D, 4B-D). Ring canals are open cytoplasmic channels that allow cell content (the cytoplasm with organelles) to be shared between cells and the cytophore and vice versa. Each ring canal was comprised of a broad cytoplasmic strand and the plasma membrane, which, especially in the case of oocytes, was lined on the inner side by electron-dense accumulation of fibrous material (Figs. 
$2 \mathrm{C}, 3 \mathrm{D}, 4 \mathrm{~B}-\mathrm{D})$. This plasma membrane modification is known as an inner bridge rim. Within the ring canal cytoplasmic strand, organelles such as mitochondria and endoplasmic reticulum (ER) were observed (Figs. 3D, 4B-D). Because the number of cells interconnected into a cyst was rather high and there were no clear borders between individual cysts, neither the exact number of cells in a given cyst nor the number of cysts per ovary cord was counted.

The morphology and ultrastructure of interconnected germ cells changed as oogenesis progressed. Initially, in the apical region of the cord, all clustered germ cells had similar ultrastructure (Figs. 2B, 3A) and the cytophore was inconspicuous and only visible on ultrathin sections (not shown). We interpreted these cells as oogonia because of their localization at the apical end of the ovary cord; their nuclei contained small nucleoli, chromatin was rather dispersed, and cytoplasm contained mainly mitochondria, whereas the ER was poorly developed (Figs. 2B, 3A). Non-meiotic characteristics of nuclei of these cells and the fact that some of them divided mitotically (not shown) were additional lines of evidence that indicated that these cells were oogonia. Below the oogonia and towards the middle part of the cord, cells entering prophase I of meiosis were found (Fig. 3B). These cells seemed to be bigger than oogonia on sections, and their nuclei contained meiotic chromosomes with synaptonemal complexes (Fig. 3B).

The cytological properties of germ cells found in the middle region of the ovary cords were different in immature and sexually mature specimens. In immature specimens, there were no growing oocytes on the cord surface (Fig. 1D) and all germ cells had similar ultrastructure; their nuclei contained dispersed chromatin - no condensed meiotic chromosomes were visible - and prominent nucleoli, and their cytoplasm mainly contained mitochondria (Fig. 4A). These cells could be interpreted as clustering germ cells that had already entered meiosis prophase I but were not yet differentiated into oocytes or nurse cells (see below), or they were already differentiated into one of the abovementioned cell 
categories but there were no morphologically detectable markers. The cytophore interconnecting these undifferentiated germ cells was still poorly developed; it mainly contained mitochondria (not shown).

In sexually mature leeches during breeding season, two morphologically distinct categories of germ cells occurred within this part of the cord (cells interpreted as nurse cells and oocytes; Figs. 1E, F, 2A, C). The fates of nurse cells and oocytes were different. Nurse cells did not gather nutrients and did not continue meiosis, and they degenerated in the distal part of the ovary cord (see below), whereas oocytes continued oogenesis and had potential to become functional gametes. Nurse cells were much more numerous than oocytes; they were roughly rounded cells, and their nuclei had lucent nucleoplasm and prominent nucleoli (Figs. 2A, C, 4B). Their cytoplasm was rich in ribosomes, mitochondria, and accumulations of glycogen granules (Fig. 4B). Nurse cells were still connected to the cytophore by ring canals (Fig. 4B). The cytophore found in the middle part of the ovary cord was more voluminous, had the form of convoluted cytoplasmic strands snaking between germ cells (Fig. 2C), and contained numerous mitochondria and ribosomes (Fig. 4B). A set of germ cells continued growing; they became bigger than nurse cells and gradually protruded from the cord (Fig. 1E, F) until they fully detached from the cord and freely floated in the ovisac lumen (Fig. 2A). These cells were recognized as oocytes. The cytoplasm volume of oocytes connected to the cord increased, and numerous ribosomes, mitochondria, and accumulations of glycogen were found (Fig. 3C-E). These oocytes were termed previtellogenic oocytes. Similar to nurse cells, previtellogenic oocyte nuclei had electron-lucent nucleoplasm and dense nucleoli (Figs. 2A, C, 3C, 4A, B). In contrast to nurse cells, the oocyte plasma membrane (oolemma) formed microvilli (Fig. 3C, E). Growing previtellogenic oocytes remained connected to the cytophore by ring canals; because of the thick layer of filamentous dense material forming the inner bridge rim (Fig. 3D inset), oocyte ring canals could be detected even on semi-thin sections 
(Fig. 2C). Growing oocytes were clearly visible on the cord surface (Fig. 1E, F); then, they eventually detached from the cord and floated within the ovisac cavity and absorbed nutrients (Figs. 2A, 5A). Such vitellogenic oocytes were the most voluminous germ cells found within ovisacs, reaching on average $68.8 \mu \mathrm{m}$ in diameter $(\mathrm{N}=10)$. They had already accumulated cytoplasm with ribosomes and mitochondria; reserved material was in the form of glycogen granules and large accumulations of lipid droplets, whereas electron-dense spheres of material that resembled proteinaceous yolk were rare (Fig. 5A, B). Nuclei of such large, vitellogenic oocytes were located in the cell centre and still contained prominent nucleoli and electronlucent nucleoplasm (Fig. 5A). The shape of the vitellogenic oocyte nucleus could be irregular; sometimes, the nucleus outline was so extremely irregular that individual fragments of nucleus were observed on sections (Fig. 5C). In the case of nurse cells, no such irregular nuclei were observed. As oocytes grew, their oolemma became smoother, i.e. microvilli gradually disappeared (Fig. 5 B, C). We never observed oocytes in metaphase of meiosis I, so we were not able to describe the final stages of oogenesis after meiosis resumed.

The basal (degenerating) end of the cord contained degenerating nurse cells and the cytophore (Figs. 1F, 2A, D, E, 4C, D). Most of the nurse cells observed in this area had large nuclei (with prominent nucleoli), which had a tendency to be located in close proximity of the ring canals, and nurse cell nuclei were even found within the cytophore (Figs. 2E, 4C, D). Mitochondria in such nurse cells were rare; sometimes, small cisternae of ER and electronlucent accumulations of glycogen granules occurred (Fig. 4C, D). Some nurse cells underwent apoptosis (Fig. 2A, D). Additionally, some apoptotic oocytes were found (Fig. 2A).

\subsection{Somatic cells}

Somatic cells formed the ovary wall, which is known as the ovisac. They also tightly adhered to the germ-line cells; together, they formed the ovary cords (Fig. 2A). A separate 
category of somatic cells was coelomocytes, which freely floated within the ovisac cavity (Fig. 2A); however, analysis of coelomocyte ultrastructure and functioning was not the goal of this study.

The ovisac was comprised of two layers of flattened epithelial cells; between them, a thick layer of a connective tissue occurred (Fig. 6A). Within the ovisac, numerous spermatozoa were sometimes found (Fig. 6A). Somatic cells adhered to germ cells within ovary cords because of their ultrastructural properties and possible functions, and these cells can be divided into three categories: the single apical cell, cells that compose the cord envelope, and the so-called internal somatic cells. The last two categories are follicular cells, because they accompany developing germ cells.

The apical cell was located at the apical tip of each ovary cord and was surrounded by oogonia (Figs. 1B, 2B). This cell was the biggest somatic cell within the ovary cord, with a maximal measured length (along the long axis) of $60 \mu \mathrm{m}$; it was irregular in shape and looked comet-like in semi-thin sections (Fig. 2B). Its nucleus contained dispersed chromatin, a prominent nucleolus, and a thick layer of nuclear lamina (Fig. 6B). Their cytoplasm was enriched in mitochondria and numerous cytoskeletal elements (Fig. 6B, C). The apical cell formed broad cytoplasmic projections that penetrated spaces between neighbouring oogonia (Fig. 6B, C). The apical cell closely adhered to the oogonia by cell junctions resembling spot desmosomes (adherens junctions) (Fig. 6C). A single apical cell was usually found at the apical tip of the cord; only in one case were two apical cells observed in the same cord (not shown). Follicular cells that formed the ovary cord envelope were flattened cells that covered all categories of germ cells (Figs. 2A-E, 3D, E, 4A, C, 5A, B, 6D). Follicular cells were usually not rich in cell organelles; they contained mitochondria and short profiles of rough ER. Additionally, their function was mainly mechanical - they formed numerous cell adherens junctions (Fig. 6D). Some follicular cells enveloping previtellogenic oocytes that 
protruded from the ovary cord had ultrastructural properties similar to those of the apical cell; the nuclei in both cell categories had a thick layer of nuclear lamina, cytoplasm enriched with mitochondria, Golgi complexes, and numerous cytoskeletal elements (compare Fig. 6B and 6C). Internal follicular cells were located within the cord, between germ cells (Figs. 2C-E, 3B, 4C, D, 6F). These cells were irregular in shape, and their cytoplasm was poor in ribosomes and were usually lighter than the cytoplasm of surrounding cells (Figs. 2C-E, 3B, 4C, D, 6F). Internal follicular cells were especially abundant in the degenerating end of the ovary cord (Fig. 2E).

\section{Discussion}

\subsection{Ovary cord comparison between in H. japonica and other leeches}

We found that the female reproductive system in H. japonica is broadly similar to that in other haemadipsids. The paired sac-like ovaries are connected via the short lateral and common oviduct to the massive vaginal sac, which in turn is connected to the gonopore via the vaginal duct. A similar scheme was found in other haemadipsids, both in the genus Haemadipsa (e.g. H. sylvestris - Borda and Siddall, 2008; H. rjukjuana, H. picta - Lai and Chen, 2010) and in other genera such as Chtonobdella (e.g. Idiobdella, C. seychellensis Borda and Siddall, 2008), Tritetrabdella (T. taiwana - Lai and Chen, 2010; T. longiductaNakano et al., 2016), and Sinospelaeobdella (S. wulingensis - Huang et al., 2019). Borda and Siddall (2008) called the central and most massive part of the reproductive tract an oviducal glandular sac; however, we prefer the term vaginal sac because of the well-developed musculature (authors' unpublished observations).

Hirudinid ovaries contain internal units comprised of germ-line cysts tightly associated with somatic cells. The organization of these internal ovarian units differ between taxa and seem to be conservative, at least at the family level. In the majority of analyzed leeches (i.e. in 
all glossiphoniids and arhynchobdellidan leeches studied to date), thin and elongated cord-like structures are enclosed within ovisacs; these ovarian units are known as ovary cords or ovary strings (Fernández et al., 1992; Świątek, 2006, 2008; Świątek et al., 2010; Ben Ahmed et al., 2010; Urbisz et al., 2014). Alternatively, in fish leeches (piscicolids), ovisacs contain numerous ball-like ovarian units termed egg follicles (Jörgensen, 1913; Spałek-Wołczyńska et al., 2008).

Detailed microscopic analysis performed in recent years has revealed that ovary cord organization and functioning differ between taxa and can be classified into three types (reviewed in Świątek and Urbisz, 2019). These types were named using the generic names of the best-known representatives; thus, there are 'Hirudo', 'Erpobdella', and 'Glossiphonia' types of ovary cords. The fourth, substantially different category comprises the abovementioned egg follicle characteristic of fish leeches, and is known as 'Piscicola' type (Świątek and Urbisz, 2019). 'Hirudo' ovary cords, originally described in Hirudo medicinalis and Haemopis sanguisuga (Świątek, 2008) and later in H. troctina and Limnatis nilotica (Ben Ahmed et al., 2010), are elongated and polarized structures, with the germ cells in the consecutive developmental stages located sequentially along the long cord axis. The apical part of the 'Hirudo' cord is club-shaped and contains oogonia and germ cells entering meiosis. The middle part is thread-like and is where germ cells diversify into oocytes (future egg cells) that gradually grow and protrude into the ovisac cavity and nurse cells which supply oocytes with cell organelles (see section 4.2). In the basal end of the cord, the nurse cells are eliminated via apoptosis (Świątek, 2008; Świątek and Urbisz, 2019). After detaching from cords, oocytes continue absorbing nutrients that freely float within the ovisac lumen. Additionally, a peculiar somatic cell (the apical cell) is located at the tip of the club-shaped apical part of the 'Hirudo' cord. In all Erpobdelliformes studied to date, 'Erpobdella' ovary cords have been found (Świątek et al., 2010, Ben Ahmed et al., 2013). The organization of 
'Erpobdella' cords is quite similar to that of 'Hirudo' cords; in both cases, cords are functionally polarized, with germ cells developing through consecutive stages of oogenesis along the long cord axis, and the apical cell occurs at the cord tip. The main differences are the number and shape of the cords (in Erpobdelliformes, there are usually several - up to $10-$ conically shaped cords within each ovisac) and that erpobdellid leech vitellogenic oocytes are retained within the cord (for details, see Świątek and Urbisz, 2019). Both 'Hirudo' and 'Erpobdella' ovary cords seem to have evolved from one ancestral form in Arhynchobdellida progenitors, and this supports the group monophyly. 'Glossiphonia' cords are characteristic of Glossiphoniidae. Superficially, they are similar to 'Hirudo' cords, but germ cells develop more or less synchronously; i.e. ovary cords are not polarized, there are no clear zones, and the apical cell is absent (Świątek and Urbisz, 2019). These differences may reflect the evolutionary split between rhynchobdellid and arhynchobdellid leeches. The fourth system, egg follicles of 'Piscicola' type, is characteristic of Piscicolidae and is substantially different from ovary cords that are characteristic of other leeches (for details, see Świątek and Urbisz, 2019). Therefore, this system seems to have independently evolved in this group of leeches. In each $H$. japonica ovisac, we found two elongated ovary cords whose overall morphology, internal organization, and functioning matched 'Hirudo' cords. In both cases ('Hirudo' and H. japonica cords), three morphologically different zones can be distinguished, and oocytes grow in the middle cord zone and finally detach from cords and complete oogenesis in the ovisac lumen. Moreover, we found the prominent apical cell in H. japonica at the cord apical tip. Even the number of ovary cords per ovisac (two) is the same in $H$. japonica and other previously studied hirudiniform leeches (Świątek, 2008; Ben Ahmed et al., 2010). Therefore, in all hirudiniform leeches analyzed to date, including $H$. japonica, the ovary cords have the same type of organization and functioning and all can be classified as 'Hirudo' type. 
To date, 'Hirudo' cords have been exclusively found in hirudiniform leeches, including representatives of genera such as Hirudo, Haemopis, Limnatis and Haemadipsa (Świątek 2008; Ben Ahmed et al. 2010; this study). Moreover, such ovary cords were recently observed in Macrobdella decora (P. Świątek and M. Siddall unpublished results). The identity of ovary cord organization in all hirudiniform leeches analyzed to date strongly supports the monophyly of Hirudiniformes, as was suggested by the ground of traditional methods in taxonomy and classification (Sawyer, 1986) and further supported by molecular analysis (Borda and Siddall, 2004). Thus, the 'Hirudo' type ovary cord can be considered an apomorphy of hirudiniform leeches. However, these features of ovary cords may not help resolve the complicated phylogenetic relationships within Hirudiniformes (e.g. Borda and Siddall, 2004; Phillips and Siddall, 2009), because the same 'Hirudo' cords have been found in all species studied to date. Of course, the ovisac and ovary cord organization in the majority of hirudiniform leeches, including haemadipsids, is not known and awaits discovery.

\subsection{Germ-line cysts and oogenesis}

Despite the different overall morphology, ovarian subunits found in leeches (ovary cords and egg follicles) are generally made up of germ cells united into syncytial cysts that are closely associated with somatic cells (Fernández et al., 1992; Świątek, 2006, 2008; Ben Ahmed et al., 2010; Świątek et al., 2010; Urbisz et al., 2014). In leeches, germ-line cells found in ovary cords and egg follicles are not individual cells, but form multicellular and in fact syncytial structures known as cysts, clones, or clusters (Świątek and Urbisz, 2019). Such syncytial cysts of germ cells are also characteristic of non-leech Clitellata (only one exception was found; see Świątek et al., 2016), some 'Polychaeta' (Brubacher and Huebner, 2011), and other animals, e.g. numerous arthropods (Büning, 1994; Jaglarz et al., 2014; Bilinski et al., 2017), some tardigrades (Poprawa et al., 2015; Janelt et al., 2020), and certain vertebrates 
(Kloc et al., 2004; Lei and Spradling, 2016; Żelazowska and Fopp-Bayat, 2019). However, we should keep in mind that female germ-line cyst formation is not a universal phenomenon; in some animals (e.g. nereid polychaetes, certain insects, chelicerates, and mollusks) cyst presence was not reported (Eckelbarger, 1983; de Jong-Brink et al. 1983; Büning, 1994; Tworzydlo et al. 2014; Jędrzejowska 2019). Germ-line cyst formation is believed to synchronize cell development and, in females, accelerate oogenesis because of diversification of cell fates: only a small set of cells (oocytes) become prospective egg cells, whereas the rest of the cells (nurse cells) transfer their cytoplasm to oocytes and eventually die (Pepling et al., 1999; Matova and Cooley, 2001; Lu et al., 2017; Yamashita, 2018).

In all clitellate annelids, germ-line cysts have a specific spatial organization; i.e. each germ cell is connected to the common central cytoplasmic mass (cytophore) by one ring canal (intercellular bridge, cytoplasmic bridge) (Świątek and Urbisz, 2019). Ring canals are modified contractile rings that do not completely close during cytokinesis and can be considered a specific kind of intercellular junction that allows the exchange of cell content (cytoplasm with macromolecules and organelles) between interconnected cells (Greenbaum et al., 2011; Haglund et al., 2011; Lu et al., 2017). In leeches, as in other clitellate annelids, interconnected germ-line cells diversify into two subpopulations: prospective oocytes, which complete oogenesis and become egg cells, and supporting nurse cells, which supply growing oocytes with organelles and macromolecules via ring canals and the cytophore (summarized in Świątek and Urbisz, 2019). Thus, leech oogenesis can be considered meroistic (Greek meros $=$ part + oon $=$ egg; Świątek and Urbisz, 2019).

In the ovary cords of $H$. japonica, we also found germ-line cysts whose general organization matched the clitellate pattern of cyst organization; each germ cell was connected to the central cytophore by one ring canal (Świątek and Urbisz, 2019). The H. japonica cyst organization is the same as in other hirudiniform leeches ('Hirudo' type). Similar to other 
Hirudiniformes studied to date (Świątek, 2008; Ben Ahmed et al., 2010), H. japonica cysts are multicellular, and neither the number of cysts per cord nor the number of interconnected cells is known because of the complicated cyst geometry and lack of clear limits between neighbouring cysts. The clustering germ cells are also morphologically diversified into oocytes and nurse cells; the latter cells eventually die in the degenerating zone of the cords, which strongly supports meroistic oogenesis. The ultrastructural properties of oocytes and nurse cells found in $H$. japonica are also very similar to those known from other hirudiniform leeches, e.g. Hirudo medicinalis (Świątek, 2008). Only oocytes form microvilli and gather cytoplasm with macromolecules and nutrients in the form of lipids and glycogen, and only a small amount of proteinaceous yolk was found. Interestingly, in some late vitellogenic oocytes of $H$. japonica, the nucleus was extremely irregularly shaped, which was not observed in other leeches. This could be connected to the well-known process of nuclear envelope disintegration in late oogenesis, which is when the oocyte restarts meiosis (the socalled oocyte nucleus breakdown; Lénárt and Ellenberg, 2003), or possibly to oocyte degeneration. Another feature worth mentioning is the thick inner rim of ring canals that interconnect the previtellogenic oocytes with the cytophore. Such a thick rim was not observed in the case of nurse cells. These dense rims are probably comprised of cytoskeletal proteins such as F-actin, which is a common component of ring canals (Haglund et al., 2011; Lu et al., 2017) and also found in leeches (Spałek-Wołczyńska et al., 2008). The function of F-actin is to stabilize the cytoplasmic channel and allow cytoplasm exchange. However, such thick rims are not common; in leeches, they have only been described in previtellogenic oocytes in Erpobdella johanssoni (Ben Ahmed et al., 2013). The ultrastructure and functioning of nurse cells and the cytophore found in H. japonica is also the same as in other Hirudiniformes (Świątek, 2008; Ben Ahmed et al., 2010), and no substantial differences were indicated. 


\subsection{Somatic cells}

Somatic cells accompany germ cells, and the important role that they play during oogenesis is well documented and discussed (e.g. Kloc and Kubiak, 2017; Clarke, 2017). In leeches, and more widely in all clitellate annelids, somatic cells also accompany germ-line cysts. Based on their histological and ultrastructural features (e.g. no signs of synthetic activity, numerous adherens junctions), it is predicted that they mainly play a mechanical role in uniting cysts into ovary cords or egg follicles; however, other roles cannot be excluded (see below) (Świątek, 2008, Spałek-Wołczyńska et al., 2008; Świątek and Urbisz, 2019). Understanding somatic cells in leech oogenesis has not usually attracted researchers' attention, with the exception of the apical cell.

In $H$. japonica, a single apical cell is also present at the tip of each ovary cord. As mentioned earlier, it is a characteristic feature of the ovary cord of the 'Hirudo' and 'Erpobdella' type ovary cords. Our analysis showed that in one case two apical cells were observed the tip of one cord. This phenomenon has not been previously described, and its importance is not known. The ultrastructural properties of the $H$. japonica apical cell are broadly similar to apical cells found in other arhynchobdellidan leeches (Świątek 2008, Świątek et al., 2010; Ben Ahmed et al., 2013, Urbisz et al., 2014). Haemadipsa japonica apical cell cytoplasm is enriched in mitochondria and not clearly identified cytoskeletal elements (probably intermediate filaments, as detected in apical cells in Hirudo medicinalis; Świątek, 2008); its nucleus has a thick layer of nuclear lamina, and the cell forms long cytoplasmic projections that penetrate the space between neighbouring cells. Moreover, the apical cell is tightly and mechanically connected to its neighbours via adherens junctions. The exact function of this peculiar cell is not known. Apart from the purely mechanical role in 
keeping the oogonia in place, it was suggested that this cell may play a role as a niche that maintains germ and/or somatic stem cells (Ben Ahmed et al., 2010).

Besides the apical cell, numerous somatic cells are associated with germ cells in $H$. japonica ovary cords. Generally, these cells can be classified as follicular cells because of their immediate contact with developing germ cells. These follicular cells seem to form subpopulations of slightly different ultrastructure and fate. One sub-population forms the ovary cord envelope, which constitutes the cord limits; these cells interact with all categories of germ cells (i.e. oogonia, nurse cells, and oocytes), and accompany vitellogenic oocytes after they have lost contact with the cord. The second sub-population includes the internal follicular cells, which are embedded inside the cords between germ-line cells. They are especially numerous in the degenerating end of the cord. Future research should determine if, aside from their mechanical functions, they are involved in germ cell degeneration. The same somatic cell categories have been described in other hirudiniform leeches (Świątek 2008, Świątek et al., 2010; Ben Ahmed et al., 2013, Urbisz et al., 2014).

\section{Summary and Conclusions}

- In H. japonica, two ovary cords are present within each ovisac.

- Ovary cords are comprised of germ-line cysts and accompanying somatic (follicular) cells.

- Germ-line cyst architecture matches the general pattern known from other clitellate annelids.

- Ovary cord morphology, cellular organization, and ultrastructural details of germ-line and somatic cells found in $H$. japonica are very similar to other hirudiniform leeches studied to date and could be classified as 'Hirudo' type ovary cords.

- Because of morphological diversification of clustering cells into oocytes and nurse cells, meroistic oogenesis is suggested. 
- The present results indicate strong conservation of ovary organization within all Hirudiniformes.

\section{Acknowledgments}

From 2012-2016, this study was funded by National Science Centre, Poland, contract [grant number DEC-2012/05/B/NZ4/02417]. Later analysis was supported financially by the Ministry of Science and Higher Education of Poland as part of the statutory activities of the Institute of Biology, Biotechnology and Environmental Protection, University of Silesia in Katowice. Part of this study was also supported by the Japan Society for the Promotion of Science, KAKENHI [grant numbers JP17K20064 and JP18K14780]. We thank Dr Łukasz Chajec (University of Silesia in Katowice) for technical assistance and providing a schematic diagram of haemadipsid ovary, Dr Mallory Eckstut (Edanz Group) for editing a draft of this manuscript, and Dr Koshiro Eto (Kitakyushu Museum of Natural History \& Human History), Dr Ko Tomikawa (Hiroshima University), and Yoshiko Yamane for their help collecting Haemadipsa leeches.We thank all of the reviewers for their valuable comments, which helped improve the manuscript. 


\section{References}

Ben Ahmed, R., Fuchs, A.Z., Tekaya, S., Harrath, A.H., Świątek, P., 2010. Ovary cords organization in Hirudo troctina Johnson, 1816 and Limnatis nilotica (Savigny, 1822) (Clitellata, Hirudinea). Zool. Anz. 249, 201-207.

Ben Ahmed, R., Tekaya, S., Małota, K., Świątek, P., 2013. An ultrastructural study of the ovary cord organization and oogenesis in Erpobdella johanssoni (Annelida, Clitellata: Hirudinida). Micron 44, 275-286.

Ben Ahmed, R., Bacchetta, R., Boesi, R., Froman, N., Marotta, R., Ferraguti, M., 2015. The spermatozoa of Hirudinea with examples from three different taxa. Zool. Anz. 255, 54-61. Blanchard, R., 1896. Hirudinees. Bolletino. Museo Regionale di Science Naturali Torino 11, $1-24$.

Blanchard, R., 1917. Monographie des Hémadipsines (Sangsues terrestres). Société de pathologie exotique 10, 640-675.

Bielecki, A., Świątek, P., Cichocka, J.M., Siddall, M.E., Urbisz, A.Z., Płachno, B.J., 2014. Diversity of features of female reproductive system and other morphological characters in leeches (Citellata, Hirudinida) in phylogenetic conception. Cladistics 30, 540-554.

Bilinski, S.M., Kubiak, J.Z., Kloc, M. 2017. Asymmetric divisions in oogenesis. In: Tassan J.P., Kubiak J.Z. (Eds.). Asymmetric Cell Division in Development, Differentiation and Cancer. Results and Problems in Cell Differentiation 61. Springer, pp. 211-228.

Borda, E., Siddall, M.E., 2004. Arhynchobdellida (Annelida: Oligochaeta: Hirudinida): Phylogenetic relationships and evolution. Mol. Phyl. Evol. 30, 213-225.

Borda, E., Oceguera-Figueroa, A., Siddall, M.E., 2008. On the classification, evolution and biogeography of terrestrial haemadipsoid leeches (Hirudinida: Arhynchobdellida: Hirudiniformes). Mol. Phyl. Evol. 46, 142-154. 
Borda, E., Siddall M.E., 2011. Insights into the evolutionary history of Indo-Pacific bloodfeeding terrestrial leeches (Hirudinida: Arhynchobdellida: Haemadipisdae). Invert. Sys. $24,456-472$.

Brubacher, J.L., Huebner, E., 2011. Evolution and development of polarized germ cell cysts: new insights from a polychaete worm Ophryotrocha labronica. Dev. Biol. 357, 96-107. Büning, J., 1994. The insect ovary: ultrastructure, previtellogenic growth and evolution. London: Chapman \& Hall.

Clarke, H., 2017. Control of mammalian oocyte development by interactions with the maternal follicular environment. In: Kloc, M., (Ed). Oocytes. Maternal Information and Functions. 2017. Results and Problems in Cell Differentiation 63. Springer, pp. 17-42. Eckelbarger, K.J., 1983. Evolutionary radiation in polychaete ovaries and vitellogenic mechanisms: their possible role in life history patterns. Can J Zool. 61, 487-504.

Fahmy, M., Ravelomanantsoa, N.A.F., Youssef, S., Hekkala, E., Siddall M., 2019. Biological inventory of Ranomafana National Park tetrapods using leech-derived iDNA. Eur. J. Wildl. Res. $65,70$.

Fernández, J., Tellez, V., Olea, N., 1992. Hirudinea. In: Harrison, F.W., Gardiner, S.L. (Eds.), Microscopic Anatomy of Invertebrates, vol. 7. Wiley-Liss, New York, pp. 323-394.

Govedich, F.R., Moser, W.E., 2015. Clitellata: Hirudinida and Acanthobdellida. In: Thorp J.H., Rogers, D.C., (Eds.) Thorp and Covich's freshwater invertebrates, Ecology and general biology. Elsevier, London, pp. 565-588.

Greenbaum, M.P., Iwamori, T., Buchold, G.M., Matzuk, M.M. 2011. Germ cell intercellular bridges. Cold Spring Harb. Perspect. Biol. 3, a005850.

Haglund, K., Nezis, I.P., Stenmark, H. 2011. Structure and functions of stable intercellular bridges formed by incomplete cytokinesis during development. Commun. Integr. Biol. 4, 1-9. Hanya, G., Morishima, K., Koide, T., Otani, Y., Hongo, S., Honda, T., Okamura, H., Higo, 
Y., Hattori, M., Kondo, Y., Kurihara, Y., Jin, S., Otake, A., Shiroisihi, I., Takakuwa, T., Yamamoto, H., Suzuki, H., Kajimura, H., Hayakawa, T., Suzuki-Hashido, N., Nakano, T., 2019. Host selection of haematophagous leeches (Haemadipsa japonica): Implications for iDNA studies. Ecol. Res. 34, 842-855.

Huang, T., Liu, Z., Gong, X., Wu, T., Liu, H., Deng J., Zhang Y., Peng Q., Zhang L., Liu, Z., 2019. Vampire in the darkness: a new genus and species of land leech exclusively bloodsucking cave-dwelling bats from China (Hirudinda: Arhynchobdellida: Haemadipsidae). Zootaxa 4560, 257-272.

Jaglarz, M.K., Kubrakiewicz, J., Jedrzejowska, I., Goldyn, B., Bilinski, S.M., 2014.

Ultrastructural analysis of the ovary and oogenesis in Spinicaudata and Laevicaudata (Branchiopoda) and its phylogenetic implications. Zoology 117, 207-215.

Janelt, K., Jezierska, M., Student, S., Poprawa, I., 2020. Structure of the germarium and female germ-cell clusters in Thulinius ruffoi (Bertolani, 1982) (Tardigrada: Eutardigrada: Parachela). Zool. J. Linn. Soc. 188, 776-787.

Jędrzejowska I., 2019. Morphology of ovaries and oogenesis in chelicerates. In: Tworzydlo W., Bilinski S., (Eds.), Evo-Devo: Non-model species in cell and developmental biology. Results and problems in cell differentiation 68. Springer, pp. 477-494.

Jong-Brink de, M., Boer, H.H., Joosse, J., 1983. Mollusca. In: Adiyodi K.G., Adiyodi R.G. (Eds.), Reproductive biology of invertebrates, Oogenesis, oviposition, and oosorption, vol I. Wiley, Chichester, pp. 397-354.

Jörgensen, M., 1913. Zellstudien II. Die Ei und Nahrzellen von Piscicola. Arch. Zellforsch. $10,127-160$

Kloc, M., Biliński, S., Dougherty, M.T., Brey, E.M., Etkin, L.D., 2004. Formation, architecture and polarity of female germline cyst in Xenopus. Dev. Biol. 266, 43-61. Kloc, M., Kubiak J.Z., 2017. Exogenous molecule and organelle delivery in oogenesis. In: 
Kloc, M., (Ed.). Oocytes. Maternal Information and Functions. Results and Problems in Cell Differentiation 63. Springer, pp. 3-16.

Lai, Y.-T., Chen J-H., 2010. Leech Fauna of Taiwan. Taipei. National Taiwan University Press.

Lai, Y.-T., Nakano, T., Chen, J.-H., 2011. Three species of land leeches from Taiwan, Haemadipsa rjukjuana comb. n., a new record for Haemadipsa picta Moore, and an updated description of Tritetrabdella taiwana (Oka). ZooKeys, 139, 1-22.

Lei, L., Spradling, A.C., 2016. Mouse oocytes differentiate through organelle enrichment from sister cyst germ cells. Science 352, 95-99.

Lénárt, P., Ellenberg, J., 2003. Nuclear envelope dynamics in oocytes: from germinal vesicle breakdown to mitosis. Curr. Opin. Cell Biol. 15, 88-95.

Lu, K., Jensen, L., Lei, L., Yamashita, Y.M., 2017. Stay connected: A germ cell strategy. Trends Genet. 33, 971-978.

Matova, N., Cooley, L., 2001. Comparative aspects of animal oogenesis. Dev. Biol. 231, 291320.

Nakano, T., Jeratthitikul, E., Nguyen, T.T., Panha, S., 2016. A new species of Tritetrabdella (Hirudinida: Hirudiniformes: Haemadipsidae) from northern Indochina. Raffles B. Zool. 64, $105-116$.

Pepling, M.E., de Cuevas, M., Spradling, A.C., 1999. Germline cysts: a conserved phase of germ cell development? Trends Cell Biol. 9, 257-262.

Phillips, A.J., Siddall, M.E., 2009. Poly-paraphyly of Hirudinidae: Many lineages of medicinal leeches. BMC Evol. Biol. 9, 246.

Poprawa, I., Hyra, M., Rost-Roszkowska, M.M., 2015. Germ cell cluster organization and oogenesis in the tardigrade Dactylobiotus parthenogeneticus Bertolani, 1982 (Eutardigrada, Murrayidae). Protoplasma 252, 1019-1029. 
Sawyer, R.T., 1986. Leech Biology and Behaviour. Clarendon Press and Oxford University Press, Oxford, 1065 pp.

Schnell, I.B., Sollmann, R., Calvignac-Spencer, S., Siddall, M.E., Yu, D.W., Wilting, A., Gilbert, M.T.P. 2015. iDNA from terrestrial haematophagous leeches as a wildlife surveying and monitoring tool - Prospects, pitfalls and avenues to be developed. Frontiers Zool., 12, 24. Siddall, M.E., Burreson E.M., 1995. Phylogeny of the Euhirudinea: Independent evolution of blood feeding by leeches? Can. J. Zool. 73, 1048-1064

Spałek-Wołczyńska, A., Klag, J., Bielecki, A., Świątek, P., 2008. Oogenesis in four species of Piscicola (Hirudinea, Rhynchobdellida). J. Morphol. 269, 18-28.

Świątek, P., 2005. Oogenesis in the leech Glossiphonia heteroclita (Annelida, Hirudinea, Glossiphonidae). I. Ovary structure and previtellogenic growth of oocytes. J. Morphol. 266, $309-318$.

Świątek, P., 2006. Oogenesis in the leech Glossiphonia heteroclita (Annelida, Hirudinea, Glossiphonidae). II. Vitellogenesis, follicle cell structure and egg shell formation. Tissue Cell $38,263-270$.

Świątek, P. 2008. Ovary cord structure and oogenesis in Hirudo medicinalis and Haemopis sanguisuga (Clitellata, Annelida): remarks on different ovaries organization in Hirudinea. Zoomorphology 127, 213-226.

Świątek, P., Krok, F., Bielecki, A., 2010. Germ-line cysts are formed during oogenesis in Erpobdella octoculata (L., 1758) (Annelida, Clitellata, Erpobdellidae). Invertebr. Reprod. Dev. 54, 53-63.

Świątek, P., Płachno, B.J., Marchant, R., Gorgoń, S., Krodkiewska, M., Małota, K., Urbisz, A.Z., 2016. Germ-line cells do not form syncytial cysts in the ovaries of the basal clitellate annelid Capilloventer australis. Zool. Anz. 260, 63-71. 
Świątek, P., Urbisz, A.Z., 2019. Architecture and life history of female germ-line cysts in clitellate annelids. In: Tworzydlo W., Bilinski S., (Eds.), Evo-Devo: Non-model species in cell and developmental biology. Results and problems in cell differentiation 68. Springer, pp. $515-551$.

Tessler, M., Barrio, A., Borda, E., Rood-Goldman, R., Hill, M., Siddall, M.E., 2016.

Description of a soft-bodied invertebrate with microcomputed tomography and revision of the genus Chtonobdella (Hirudinea: Haemadipsidae). Zool. Scr. 45, 552-565.

Tessler, M., Weiskopf, S.R., Berniker, L., Hersch, R., McCarthy, K.P., Yu, D.W., Siddall, M.E., 2018. Bloodlines: Mammals, leeches, and conservation in southern Asia. Syst.

Biodivers. 16, 488-496.

Tworzydlo, W., Kisiel, E., Jankowska, W., Bilinski, S. M., 2014. Morphology and ultrastructure of the germarium in panoistic ovarioles of a basal "apterygotous" insect, Thermobia domestica. Zoology 117, 200-206.

Urbisz, A.Z., Lai, Y-T., Świątek, P., 2014. Barbronia weberi (Clitellata, Hirudinida, Salifidae) has ovary cords of the Erpobdella type. J. Morphol. 275, 479-488.

Yamashita, Y.M., 2018. Subcellular specialization and organelle behavior in germ cells. Genetics 208, 19-51.

Żelazowska, M., Fopp-Bayat, D., 2019. Germline cysts and asymmetry in early previtellogenic ovarian follicles in cultured albino females of sterlet Acipenser ruthenus L. 1758 (Chondrostei, Acipenseriformes). Protoplasma, 256, 1229-1244. 


\section{Figure Legends}

Fig. 1. Female reproductive system and general morphology of ovary cords.

A. Whole female reproductive system visualized by stereomicroscopy. ov, ovaries; lo, lateral oviduct; co, common oviduct; vs, vaginal sac; vd, vaginal duct. B. Almost the entire ovary cord from a specimen that was not in breeding season, visualized by Nomarski differential interference contrast. ap, extended apical part of the cord; md, convoluted middle part of the cord. C. Ovary cord scheme based on light and electron microscopy observations; three distinguishable zones with germ cells at the consecutive stages of oogenesis are marked. ap, apical part of the cord with large apical cell (arrow) and oogonia; md, middle part with germ cells differentiated into nurse cells (nc) and oocytes (both previtellogenic, po, and vitellogenic, vo) protruding at the ovary surface; cy, the cytophore to which germ cells are connected via the ring canals; de, distal end of the cord with germ cells undergoing degeneration; double arrows, somatic cells of the cord. D-F. Parts of ovary cords visualized by Nomarski differential interference contrast from sexually mature specimens, D. Apical tip of the cord (ap); the arrow points to the apical cell. E. Fragment of the middle part of the cord (mp). po, previtellogenic oocytes gradually protruding from the cord. F. Fragment of the middle part (mp) and distal end (de) of the cord. nc, nurse cells; po, previtellogenic oocytes. Scale bars $=400 \mu \mathrm{m}(\mathrm{A}), 54 \mu \mathrm{m}(\mathrm{B}), 27 \mu \mathrm{m}(\mathrm{D}, \mathrm{E}), 33 \mu \mathrm{m}(\mathrm{F})$.

Fig. 2. Ovary and ovary cord of sexually mature specimens visualized in semi-thin sections.

A. General overview of ovary internal organization. c, coelomocytes; de, fragment of degenerating cord end; mp, middle part of the cord; po, previtellogenic oocytes; ov, ovisac; vo, vitellogenic oocytes. The double arrows point to apoptotic nurse cells, the single arrow indicates an apoptotic previtellogenic oocyte. B. Apical tip of the cord. ac, apical cell; n, apical cell nucleus; og, oogonia. The arrow points to a somatic cell forming cord envelope. $\mathbf{C}$. 
Middle part of the cord. cy, cytophore; nc, nurse cells; po, previtellogenic oocytes; circle, ring canal interconnecting oocyte with cytophore. Arrows indicate somatic cells forming the cord envelope. The asterisk indicates cytoplasm of internal follicular cell. D, E. Transition zone between the middle part of the cord (in $\mathbf{D}$ ) and the degenerating zone (in $\mathbf{E}$ ). cy, cytophore; asterisk, internal follicular cells; nc, nurse cells; ncn, nurse cell nuclei gathered in the cytophore; po, fragment of previtellogenic oocyte. Double arrows indicate apoptotic nurse cells, single arrows point to somatic cells that form the cord envelope. Scale bars $=35 \mu \mathrm{m}$ (A), $9 \mu \mathrm{m}(\mathrm{B}), 15 \mu \mathrm{m}(\mathrm{C}, \mathrm{E}), 17 \mu \mathrm{m}$ (D).

Fig. 3. Ultrastructural details of oogonia and oocytes of sexually mature specimens. A. Oogonia (oo) located in close vicinity of the apical cell (compare with Fig. 2B). g, Golgi complex; on, oogonia nuclei; m, mitochondria. B. Germ cells (gc) in early meiotic prophase I. Double arrows indicate the synaptonemal complex. m, mitochondria; ifc, fragment of an internal follicular cell. C-D. Previtellogenic oocytes (po) located at the cord periphery (compare with Fig. 2C). Inset in D: ring canal (asterisks) interconnecting po with cytophores (cy). ga, glycogen accumulations; er, endoplasmic reticulum; fc, follicular cells; 1, lipid droplet; m, mitochondria; on, oocyte nucleus. Arrows point to microvilli, short arrows indicate bridge rims. E. Contact zone between previtellogenic oocytes (po) and follicular cells (fc). ga, glycogen accumulations; er, endoplasmic reticulum; m, mitochondria. Arrows point to oocyte microvilli, short arrows point to adherens foci between oocytes and follicular cells, the ellipse indicates an adherens junction between follicular cells. Scale bars $=2 \mu \mathrm{m}(\mathrm{A}-\mathrm{D}), 4$ $\mu \mathrm{m}$ (D inset), $1 \mu \mathrm{m}(\mathrm{E})$.

Fig. 4. Ultrastructure of germ cells and the cytophore of the sexually immature and mature specimens. 
A. Germ cells ( $\mathrm{gc})$ in the middle part of the cord in a leech that was not in breeding season. $\mathrm{m}$, mitochondria; nu, nuclei; fc, follicular cells forming the cord envelope. B. Nurse cell (nc) and cytophore (cy) in the middle zone of the cord. ga, glycogen accumulation; ifc, internal somatic cell; m, mitochondria; nu, nuclei. The asterisk indicates a ring canal, and arrows point to ring canal rims. C-D. Nurse cells (nc) and cytophore (cy) in the degenerating part of the cord. ga, glycogen accumulation; er, endoplasmic reticulum; ifc, internal follicular cells; m, mitochondria; nu, nurse cell nuclei. The asterisk indicates a ring canal, and arrows point to ring canal rims. Note one nurse cell nucleus located in the cytophore in $\mathbf{D}$. Scale bars $=3 \mu \mathrm{m}$ (A, C), $2 \mu \mathrm{m}(\mathrm{B}, \mathrm{D})$.

Fig. 5. Vitellogenic oocytes floating within the ovisac lumen.

A. Light microscopy of a fragment of ovisac filled with vitellogenic oocytes (vo). ga, glycogen accumulations; 1, lipids; on, oocyte nucleus with nucleoli; ov, ovisac. Arrows indicate follicular cells, short arrows indicate dense spherical bodies of yolk-like material. The boxed area is magnified in Fig. 5B. B. Fragments of two vitellogenic oocytes visualized in Fig. 5A. ga, glycogen accumulation; m, mitochondria. Arrows indicate follicular cells. The inset shows electron-dense accumulations of yolk-like material (asterisk). C. Vitellogenic oocyte with abundant lipid accumulations (1) and a highly lobated nucleus (on). Asterisks indicate nucleoli. $\mathrm{m}$, mitochondria. Scale bars $=14 \mu \mathrm{m}(\mathrm{A}), 2 \mu \mathrm{m}(\mathrm{B}, \mathrm{C})$.

Fig. 6. Somatic cells.

A. Ovisac wall. ct, connective tissue; ep, epithelial cells; ms, muscle cells. Note numerous spermatozoa within epithelial cells (arrows). B. Fragment of the apical cell (ap). apn, nucleus of the apical cell; f, cytoskeletal filaments; isc, internal somatic cells; m, mitochondria; og, oogonia. Arrows point to thick nuclear lamina. C. Contact zone between the apical cell (ac) 
and oogonia (og). f, cytoskeletal filaments; m, mitochondria; n, nucleus. The ellipses indicate adherens junctions. D. Follicular cells (fc) forming the cord envelope. nc, nurse cell; m, mitochondria. Arrows point to adherens junctions, asterisks indicate extracellular material. E. Follicular cell (fc) enveloping a previtellogenic oocyte (po). f, cytoskeletal filaments; g, Golgi complexes; m, mitochondria; nu, nucleus. The asterisk indicates nucleoli. F. Internal follicular cell (ifc) located among nurse cells (nc). m, mitochondria; nu, nucleus. The asterisk indicates nucleoli. Scale bars $=3 \mu \mathrm{m}$ (A, F), $2 \mu \mathrm{m}$ (B, C, E), $1 \mu \mathrm{m}$ (D). 

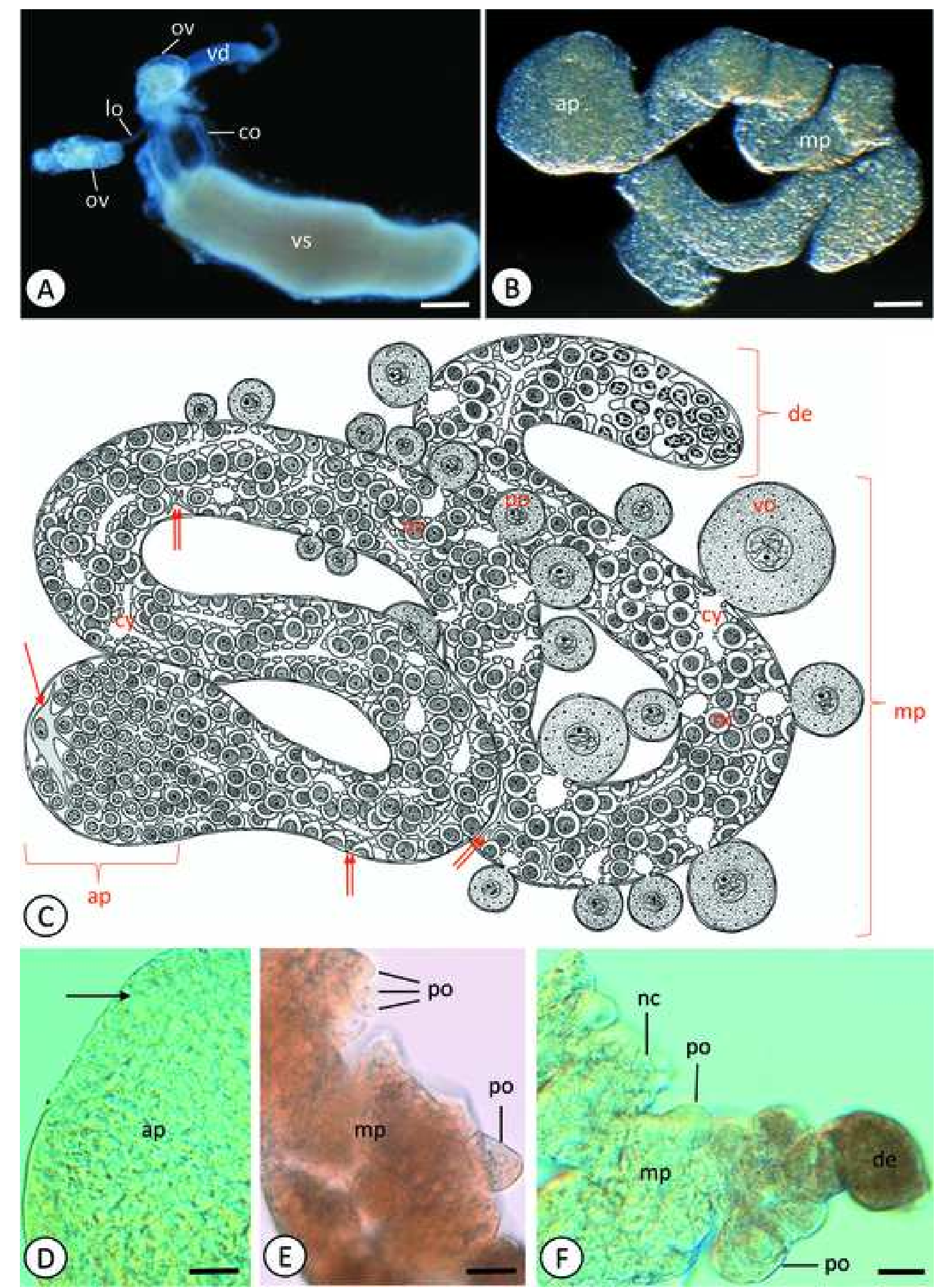

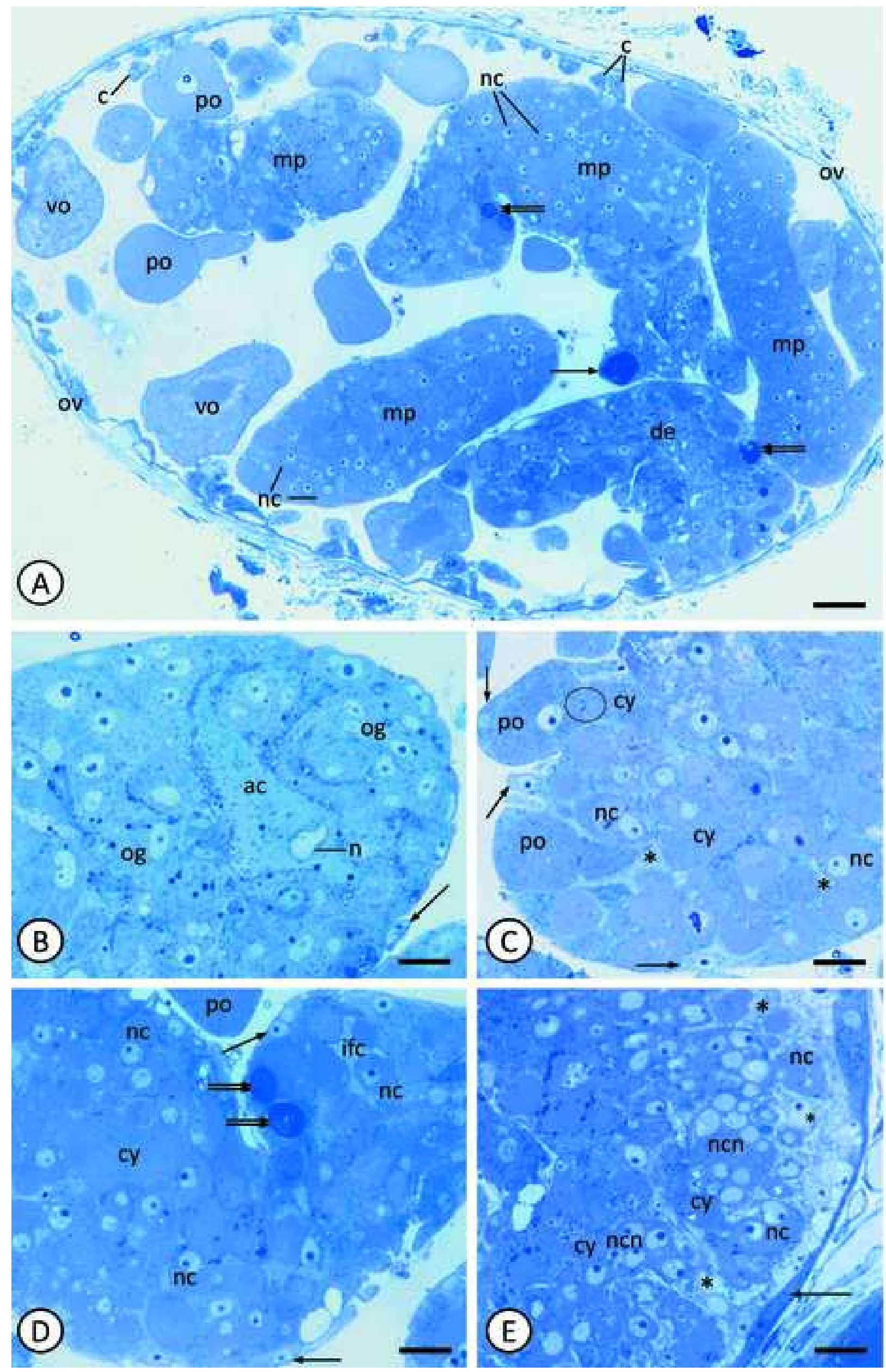

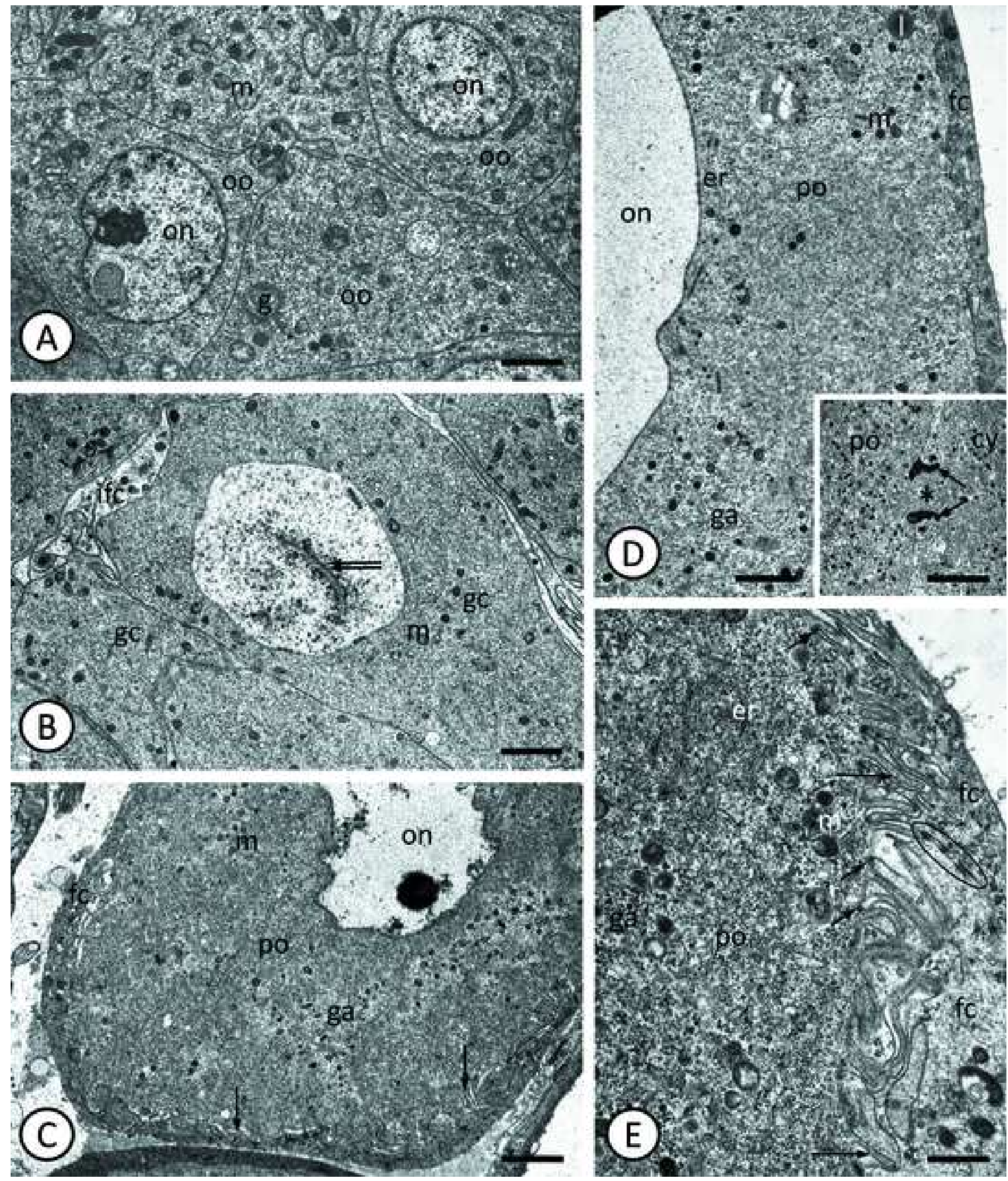

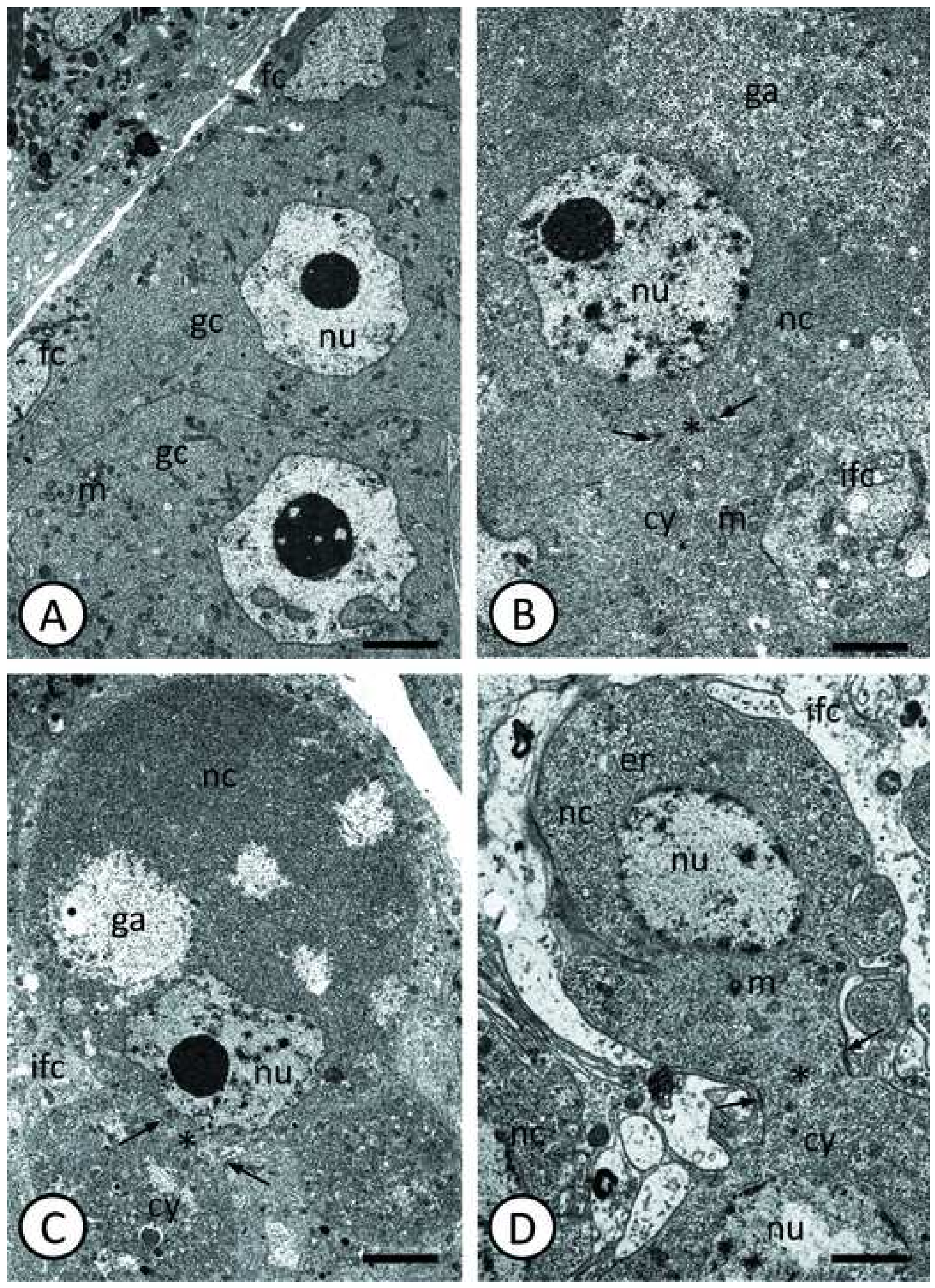

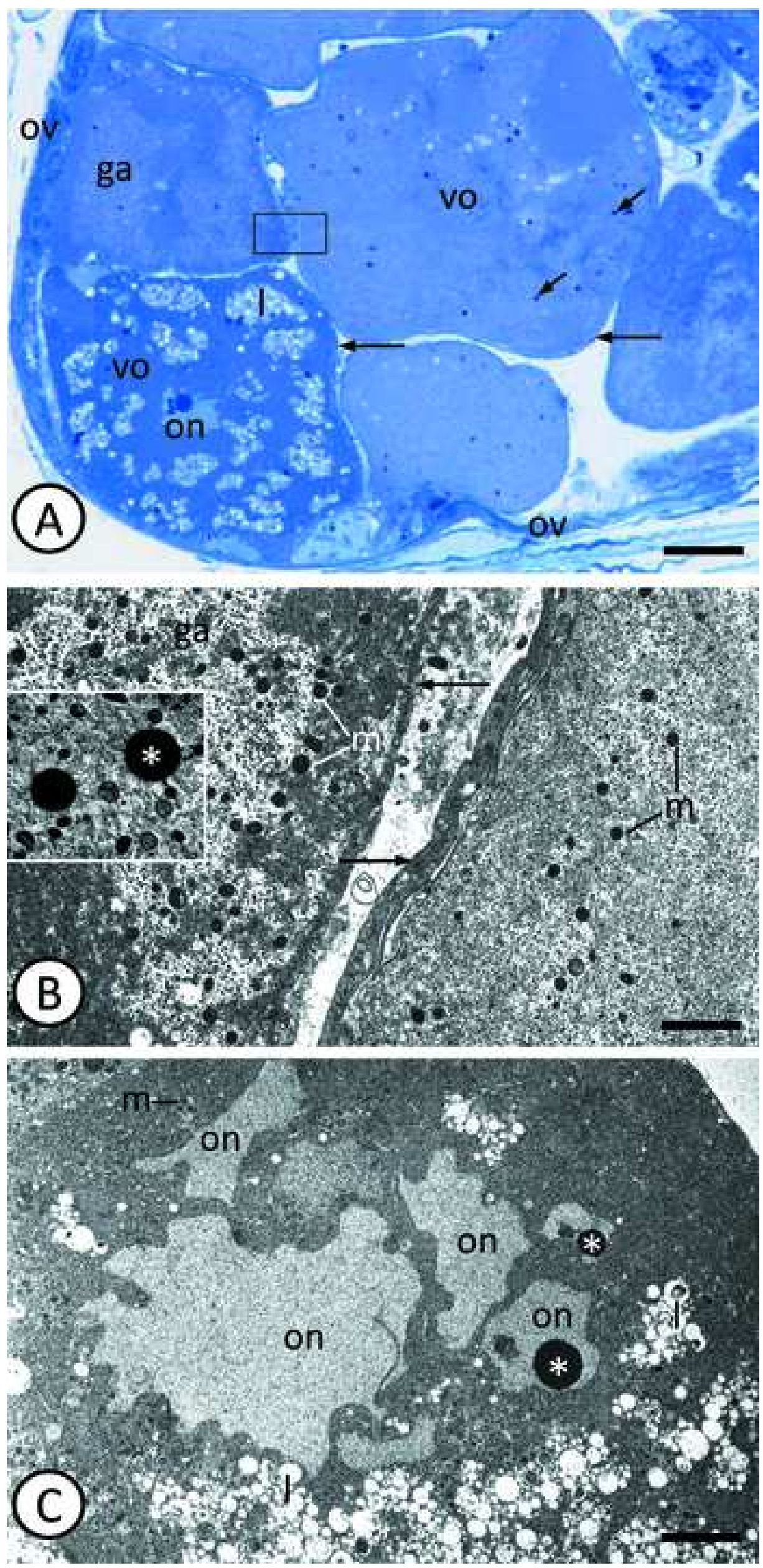


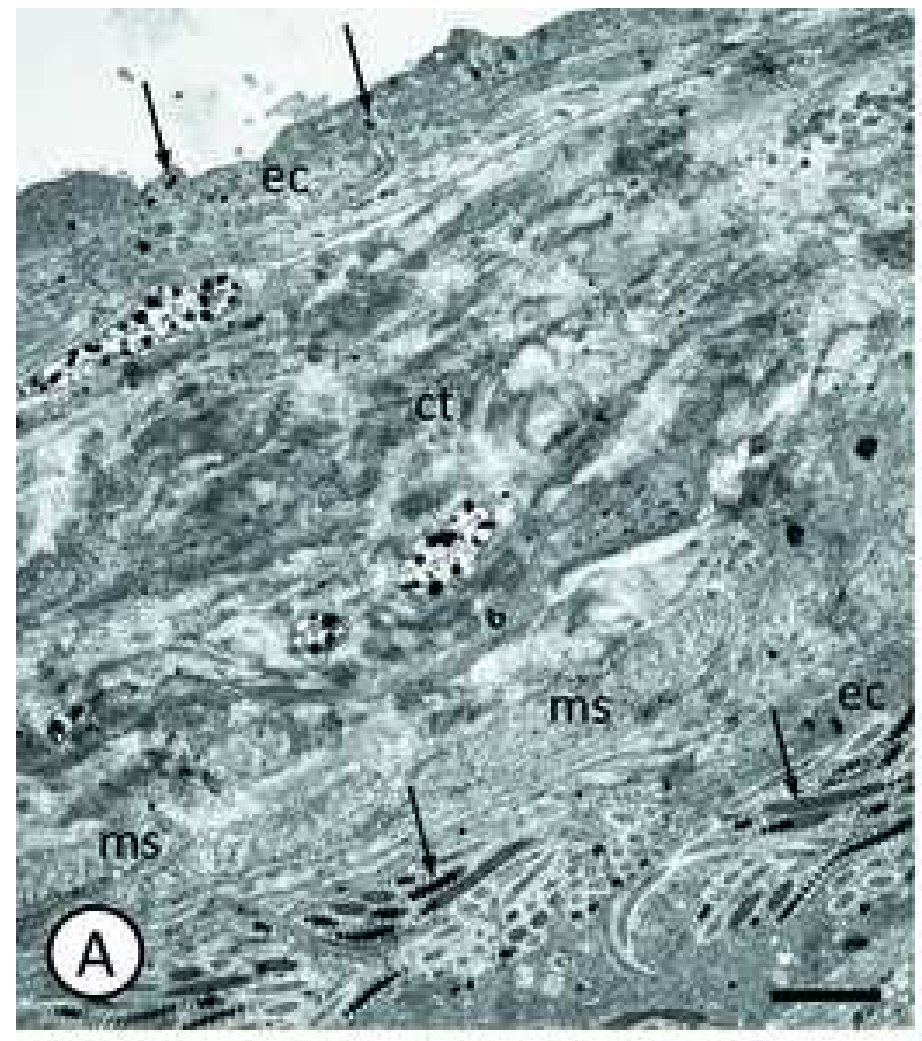

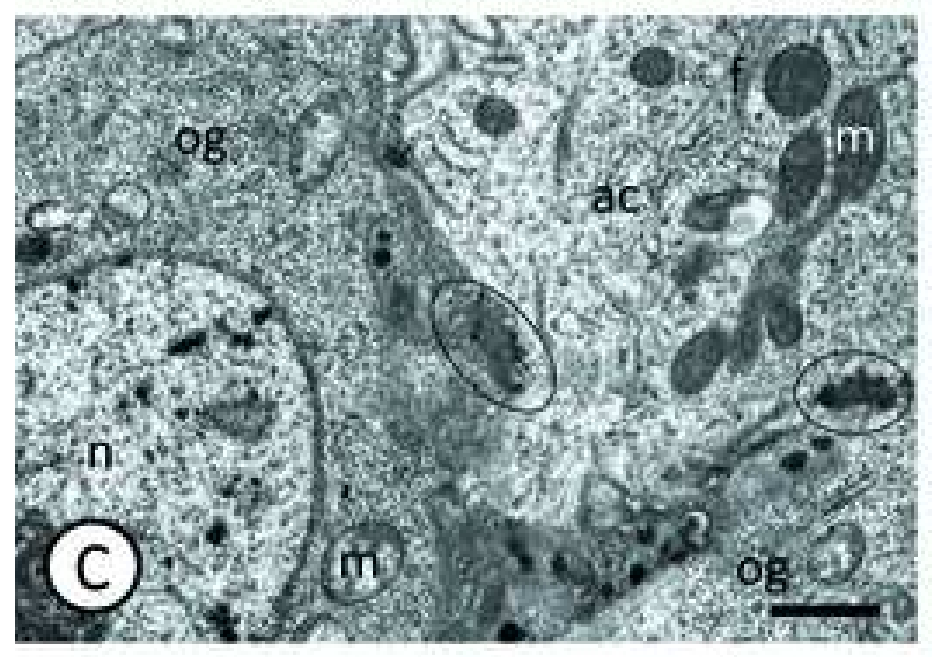

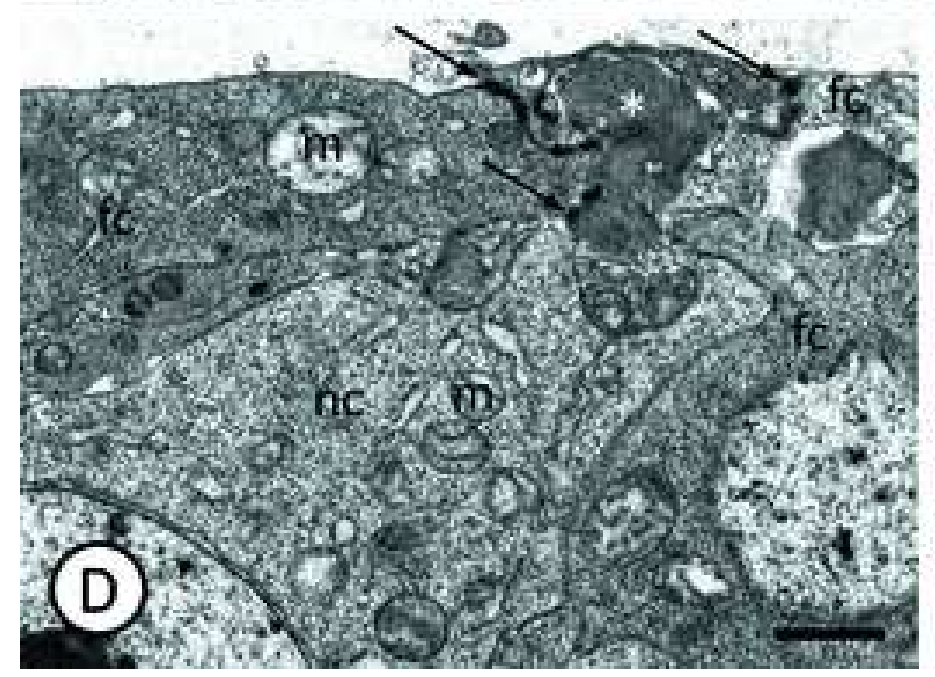

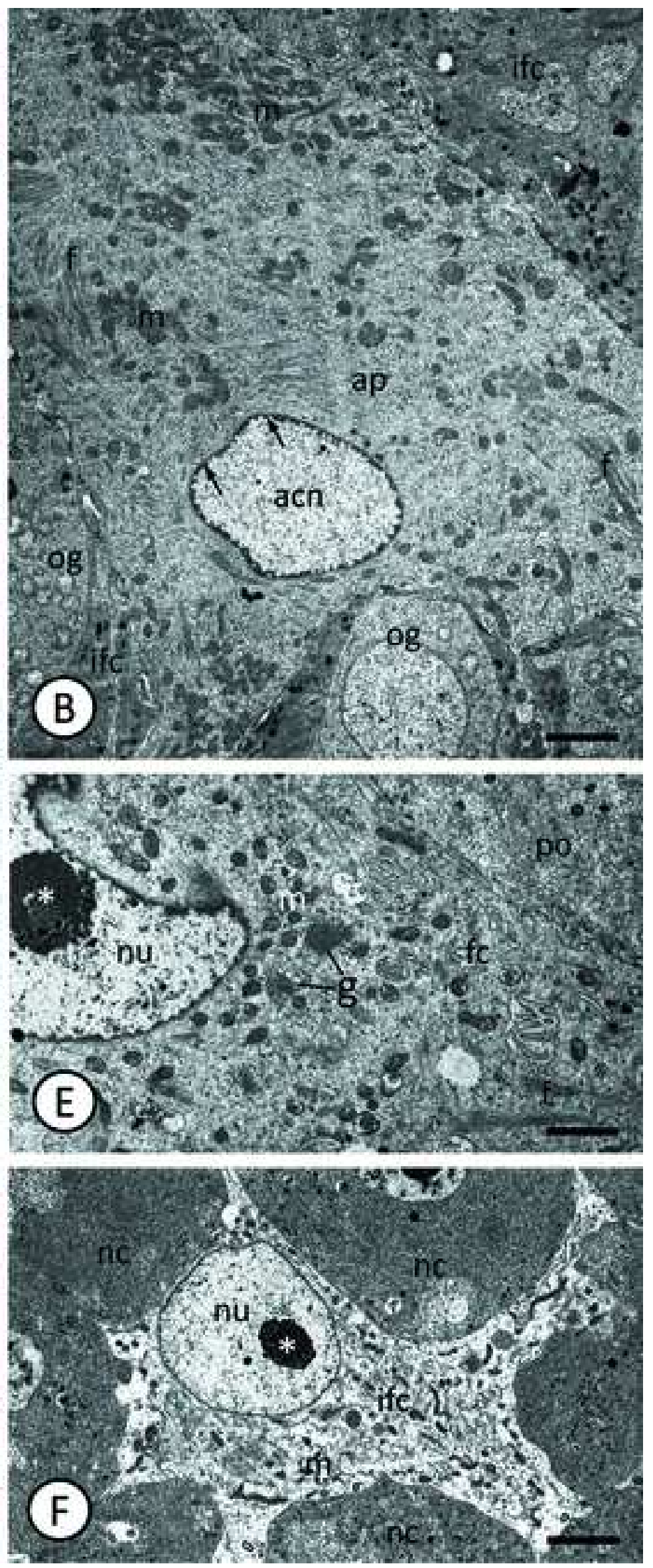




\section{Conflict of Interest}

The authors declare that they have no conflict of interests. 